Eur. J. Mineral.

2011, 23, 567-576

Published online May 2011

\title{
Trioctahedral entities in palygorskite: Near-infrared evidence for sepiolite-palygorskite polysomatism
}

\author{
ElizaBETH T. STATHOPOULOU ${ }^{1,2}$, MERCEDES SUÁREZ ${ }^{3}$, EMILIA GARCÍA-ROMERO ${ }^{4}$, MANUEL SÁNCHEZ DEL RÍO ${ }^{5}$, \\ GEORGE H. KACANDES ${ }^{6}$, VASSILIS GIONIS ${ }^{1}$ and GEORGIOS D. CHRYSSIKOS ${ }^{1, *}$
}

${ }^{1}$ Theoretical and Physical Chemistry Institute, National Hellenic Research Foundation, 48 Vassileos Constantinou Avenue, 11635 Athens, Greece

*Corresponding author, e-mail: gdchryss@eie.gr

${ }^{2}$ Department of Historical Geology and Palaeontology, Subfaculty of Geology \& Geoenvironment,

University of Athens, Panepistimiopolis, Zografou, 15784 Athens, Greece

${ }^{3}$ Departamento de Geología, Universidad de Salamanca, 37008 Salamanca, Spain

${ }^{4}$ Departamento de Cristalografía y Mineralogía, Universidad Complutense de Madrid, 28040 Madrid, Spain

${ }^{5}$ European Synchrotron Radiation Facility, BP 22038043 Grenoble, Cedex, France

${ }^{6}$ Geohellas S.A., 8A Pentelis Street, 17564 Athens, Greece

\begin{abstract}
The mixed dioctahedral-trioctahedral character of $\mathrm{Mg}$-rich palygorskite has been previously described by the formula $y \mathrm{Mg}_{5} \mathrm{Si}_{8} \mathrm{O}_{20}(\mathrm{OH})_{2}\left(\mathrm{OH}_{2}\right)_{4} \cdot(1-y)\left[x \mathrm{Mg}_{2} \mathrm{Fe}_{2} \cdot(1-x) \mathrm{Mg}_{2} \mathrm{Al}_{2}\right] \mathrm{Si}_{8} \mathrm{O}_{20}(\mathrm{OH})_{2}\left(\mathrm{OH}_{2}\right)_{4}$, where $y$ is the trioctahedral fraction of this two-chain ribbon mineral with an experimentally determined upper limit of $y \approx 0.5$ and $x$ is the Fe ${ }^{\mathrm{III}}$ content in the M2 sites of the dioctahedral component. Ideal trioctahedral $(y=1)$ palygorskite is elusive, although sepiolite $\mathrm{Mg}_{8} \mathrm{Si}_{12} \mathrm{O}_{30}(\mathrm{OH})_{4}\left(\mathrm{OH}_{2}\right)_{4}$ with a similar composition, three-chain ribbon structure and distinct XRD pattern is common. A set of 22 samples identified by XRD as palygorskite and with variable composition $(0<x<0.7,0<y<0.5)$ were studied to extrapolate the structure of an ideal trioctahedral $(y=1)$ palygorskite and to compare this structure to sepiolite. Near-infrared spectroscopy was used to study the influence of octahedral composition on the structure of the TOT ribbons, $\mathrm{H}_{2} \mathrm{O}$ in the tunnels and surface silanols of palygorskite, as well as their response to loss of zeolitic $\mathrm{H}_{2} \mathrm{O}$. All spectroscopic evidence suggests that palygorskite consists of discrete dioctahedral and trioctahedral entities. The dioctahedral entities have variable structure determined solely by $x=\mathrm{Fe}^{\mathrm{III}} /\left(\mathrm{Al}+\mathrm{Fe}^{\mathrm{III}}\right)$ and their content is proportional to $(1-y)$. In contrast, the trioctahedral entities have fixed octahedral composition or ribbon structure and are spectroscopically identical to sepiolite. The value of $d_{200}$ in palygorskite follows the regression $d_{200}(\AA)=6.362+0.129 x(1-y)+0.305 y, R^{2}=0.96, \sigma=0.013 \AA$. When extrapolated to $y=1, d_{200}$ is identical to sepiolite. Based on this analysis, we propose that palygorskite samples with non-zero trioctahedral character should be considered as members of a polysomatic series of sepiolite and (dioctahedral) palygorskite described by the new formula $y^{\prime} \mathrm{Mg}_{8} \mathrm{Si}_{12} \mathrm{O}_{30}(\mathrm{OH})_{4}\left(\mathrm{OH}_{2}\right)_{4} \cdot\left(1-y^{\prime}\right)\left[x^{\prime} \mathrm{Mg}_{2} \mathrm{Fe}_{2} \cdot\left(1-x^{\prime}\right) \mathrm{Mg}_{2} \mathrm{Al}_{2}\right] \mathrm{Si}_{8} \mathrm{O}_{20}(\mathrm{OH})_{2}\left(\mathrm{OH}_{2}\right)_{4}$, with $0<x^{\prime}=x<0.7$ and $0<y^{\prime}$ $=y /(2-y)<0.33$.
\end{abstract}

Key-words: palygorskite, sepiolite, XRD, near-infrared spectroscopy, dioctahedral, trioctahedral, polysomatism.

\section{Introduction}

Phyllosilicate minerals of the palygorskite-sepiolite group have a layer structure with alternating 2:1 ribbons (modules, Fig. 1) and tunnels containing zeolitic $\mathrm{H}_{2} \mathrm{O}$ parallel to the $c$ axis. This modulation is due to the periodic inversion of the apical oxygen atoms of the tetrahedra every two silicate chains in palygorskite, or three in sepiolite, causing the discontinuity of the octahedral sheet. The different periodicity of the silicate chain inversion allows for the clear distinction of palygorskite from sepiolite by X-ray diffraction $\left(d_{110} \approx 10.4\right.$ and $12.1 \AA$, respectively). The microstructure of these clays produces interesting absorption and rheological properties with applications in industry and materials science (Singer, 1989). For example, the Mayas used palygorskite in preparing the Maya Blue pigment, essentially exploiting the principles of molecular insertion and one-dimensional confinement to fabricate hybrid nanomaterials (van Olphen, 1966; Gómez-Romero \& Sánchez, 2005).

Both palygorskite and sepiolite were originally described as magnesian and trioctahedral $\left(\mathrm{Mg}_{5} \mathrm{Si}_{8} \mathrm{O}_{20}\right.$ $(\mathrm{OH})_{2}\left(\mathrm{OH}_{2}\right)_{4}$, Bradley, 1940; $\mathrm{Mg}_{8} \mathrm{Si}_{12} \mathrm{O}_{30}(\mathrm{OH})_{4}\left(\mathrm{OH}_{2}\right)_{4}$, Brauner \& Preisinger, 1956, respectively). Later studies made evident that palygorskite is mainly dioctahedral with four octahedral ions per $8 \mathrm{Si}$ and with about half of the $\mathrm{Mg}$ substituted by $\mathrm{Al}$ or Fe (Drits \& Aleksandrova, 1966; Drits \& Sokolova, 1971; Serna et al., 1977; Güven et al., 1992). 
$\mathrm{a} / 2$
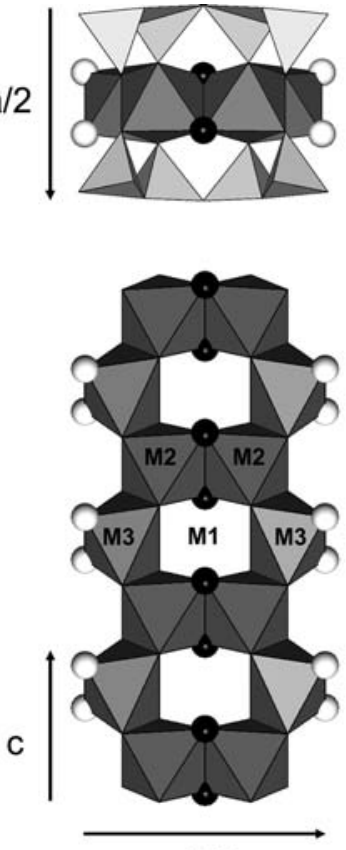

$\mathrm{b} / 2$
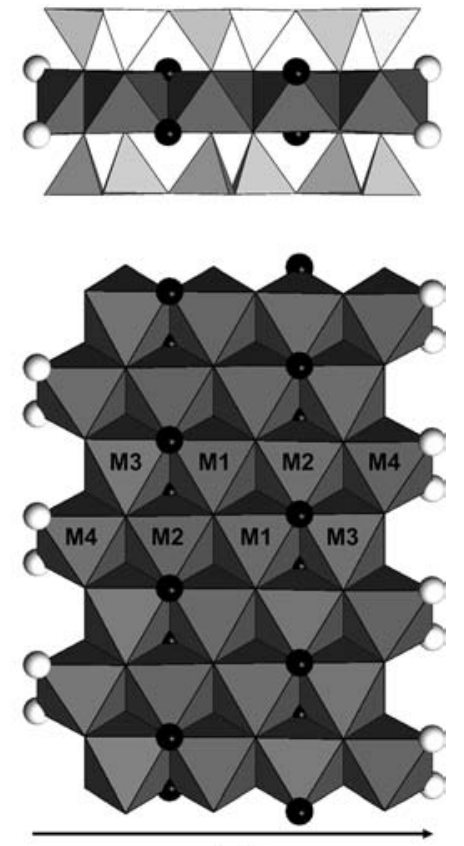

$\mathrm{b} / 2$

Fig. 1. Upper: Structure of the 2:1 ribbons of palygorskite (left) and sepiolite (right). Lower: Structure of the corresponding octahedral sheets. Dioctahedral palygorskite has a vacant M1 site. Light spheres mark coordinated $\mathrm{OH}_{2}$ terminating the octahedral sheet. Dark spheres are structural $\mathrm{OH}$.

Recent Rietveld-based synchrotron X-ray diffraction (Artioli et al., 1994; Chiari et al., 2003; Post \& Heaney, 2008) and neutron diffraction (Giustetto \& Chiari, 2004) studies of palygorskite were performed on specimens with nearly $2 \mathrm{Mg}$ and $2 \mathrm{Al}$ octahedral ions per $8 \mathrm{Si}$, i.e. close to the ideal dioctahedral formula $\mathrm{Mg}_{2} \mathrm{Al}_{2} \mathrm{Si}_{8} \mathrm{O}_{20}(\mathrm{OH})_{2}\left(\mathrm{OH}_{2}\right)_{4}$ (Fig. 1).

However, compilations of single-particle analytical data (Paquet et al., 1987; Galán \& Carretero, 1999; Suárez et al., 2007; García-Romero \& Suárez, 2010) and several mid- or near-infrared spectroscopic investigations (Chahi et al., 2002; García-Romero et al., 2004; Cai et al., 2007; Gionis et al., 2007; Chryssikos et al., 2009) indicate that samples identified by XRD as palygorskite can have more than 4 octahedral cations per $8 \mathrm{Si}$ and $\mathrm{Mg}>(\mathrm{Al}+\mathrm{Fe})$. These "Mg-rich" palygorskite samples are assigned a mixed dioctahedral - trioctahedral character.

The occupancy of the three octahedral sites (M1, M2, M3) in palygorskite by $\mathrm{Mg}, \mathrm{Al}$ and $\mathrm{Fe}$ was resolved by the $\mathrm{OH}$-overtone spectra in the near-infrared (NIR) range by Gionis et al. (2006, 2007) and is remarkably simple: Regardless of octahedral composition, the outer (M3) sites are occupied by $\mathrm{Mg}$ coordinated to four $\mathrm{O}$ atoms and two $\mathrm{OH}_{2}$ groups. $\mathrm{Al}$ and $\mathrm{Fe}^{\mathrm{III}}$ occupy adjacent $\mathrm{M} 2$ sites next to a vacant $\mathrm{M} 1$ site forming $\mathrm{AlAlOH}, \mathrm{AlFeOH}$ and $\mathrm{FeFeOH}$ units (Fig. 1). In Mg-rich palygorskite, there are also triplets of $1 \mathrm{M} 1$ and $2 \mathrm{M} 2$ sites occupied by $\mathrm{Mg}$ to form $\mathrm{Mg}_{3} \mathrm{OH}$ units. No spectroscopic evidence for structural $\mathrm{OH}$ associated with cations with a valence sum different than six, (e.g., $\mathrm{Mg}_{2} \mathrm{AlOH}, \mathrm{MgAlOH}, \mathrm{Mg}_{2} \mathrm{OH}$ ) was

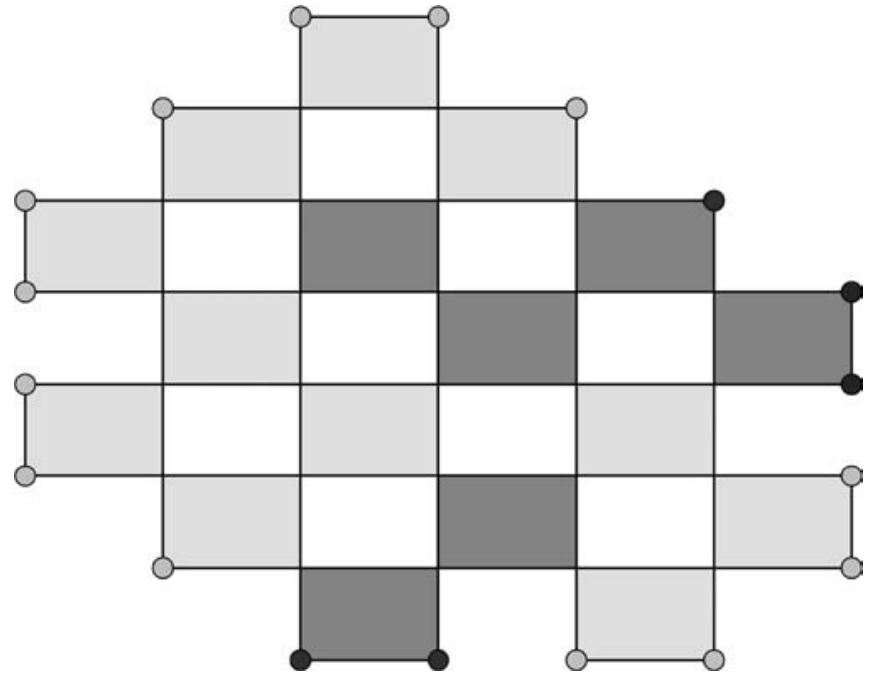

Fig. 2. Polysomatic representation of a palygorskite with $35 \%$ trioctahedral character made of randomly interlinked dioctahedral (grey) and trioctahedral (dark grey) palygorskite ribbons according to Gionis et al. (2007). SiOH groups terminating the dioctahedral or trioctahedral ribbons are depicted by open and filled circles, respectively.

found. These results led Gionis et al. (2007) to suggest that the palygorskite particles with mixed dioctahedral - trioctahedral character consist of two-chain ribbons that are either trioctahedral, $\mathrm{Mg}_{5} \mathrm{Si}_{8} \mathrm{O}_{20}(\mathrm{OH})_{2}\left(\mathrm{OH}_{2}\right)_{4}$, or dioctahedral, $\mathrm{Mg}_{2}(\mathrm{Fe}, \mathrm{Al})_{2} \mathrm{Si}_{8} \mathrm{O}_{20}(\mathrm{OH})_{2}\left(\mathrm{OH}_{2}\right)_{4}$ as in Fig. 2. According to this description the composition of palygorskite can be approximated by the formula:

$$
\begin{gathered}
y \mathrm{Mg}_{5} \mathrm{Si}_{8} \mathrm{O}_{20}(\mathrm{OH})_{2}\left(\mathrm{OH}_{2}\right)_{4} \cdot(1-y)\left[x \mathrm{Mg}_{2} \mathrm{Fe}_{2} \cdot(1-\mathrm{x})\right. \\
\left.\mathrm{Mg}_{2} \mathrm{Al}_{2}\right] \mathrm{Si}_{8} \mathrm{O}_{20}(\mathrm{OH})_{2}\left(\mathrm{OH}_{2}\right)_{4}
\end{gathered}
$$

where $x$ is the fraction of $\mathrm{Al}$ substituted by $\mathrm{Fe}^{\mathrm{III}}$ and $y$ the trioctahedral fraction.

Subsequently, Chryssikos et al. (2009) combined NIR with analytical electron microscopy and found that a set of 18 palygorskite samples from various locations conforms to formula (1) with $0<x<0.7,0<y<0.5$, and with $x$ uncorrelated to $y$. The data indicate the existence of fully ferric dioctahedral palygorskite particles $(x=1)$. However, a fully trioctahedral $\mathrm{Mg}_{5} \mathrm{Si}_{8} \mathrm{O}_{20}(\mathrm{OH})_{2}\left(\mathrm{OH}_{2}\right)_{4}$ mineral with the palygorskite two-chain ribbon structure, i.e. a $\mathrm{Mg}$ analog to yofortierite or raite (Perrault et al., 1975; Pluth et al., 1997), is unknown to our knowledge, with the possible exception of a recent report based on electron diffraction and high resolution TEM (Chen et al., 2008). Known Mg-rich samples with composition approaching $y=1$ exhibit the 110 reflection at $c a .12 \AA$. These samples are therefore identified as sepiolite consisting of threechain ribbons. On the other hand, García-Romero \& Suárez (2010) studied recently the composition of two sets of samples from various localities identified by XRD as palygorskite and sepiolite, respectively, and reported a smooth transition between palygorskite and sepiolite with no compositional gap between the two minerals. Thus, as the trioctahedral component increases, the two-chain 
$\mathrm{Mg}_{5} \mathrm{Si}_{8} \mathrm{O}_{20}(\mathrm{OH})_{2}\left(\mathrm{OH}_{2}\right)_{4}$ ribbons postulated to be present in palygorskite with $0<y<0.5$ (Gionis et al., 2007) should give place to three-chain sepiolite ribbons, $\mathrm{Mg}_{8} \mathrm{Si}_{12} \mathrm{O}_{30}(\mathrm{OH})_{4}\left(\mathrm{OH}_{2}\right)_{4}$.

The purpose of this work is to investigate the nature of the trioctahedral component of palygorskite in relationship to sepiolite. One approach is by extrapolating the structure of the ideal trioctahedral palygorskite $\mathrm{Mg}_{5} \mathrm{Si}_{8} \mathrm{O}_{20}(\mathrm{OH})_{2}\left(\mathrm{OH}_{2}\right)_{4}$ from samples with mixed dioctahedral - trioctahedral character and comparing it to sepiolite. Suárez et al. (2007) were the first to employ this strategy based on XRD and analytical data. In addition to interplanar distances, structural extrapolations can be based also on NIR spectra. Vibrational spectroscopic techniques are sensitive to bonding and symmetry differences such as those expected from the different types of ribbons in palygorskite and sepiolite. A preliminary NIR comparison of the trioctahedral sheet signature of palygorskite and sepiolite SepSp-1 (CMS Source Clays Repository, special clay) was based on their ambient spectra and failed to detect any such differences (Gionis et al., 2007). A more rigorous comparison is attempted here. This comparison relies on the NIR monitoring of the spectral changes accompanying the progressive loss of zeolitic
$\mathrm{H}_{2} \mathrm{O}$ upon mild dehydration. The as-produced series of spectra allow for the more sensitive detection of bonding rearrangements and unit cell distortions (Gionis et al., 2006) which, albeit subtle, differ in dioctahedral palygorskite and sepiolite (Post et al., 2007; Post \& Heaney, 2008).

\section{Experimental methods}

\subsection{Samples}

A set of 22 high purity palygorskite samples from various localities are included in this study (Table 1): LIL and BOT (Lisbon volcanic complex, Portugal), PAL (Palygorskaya, Perm, Russia), CAS (Cassiar, British Columbia, Canada), ATT (Attapulgus, Georgia, USA), TRA (Los Trancos, Almería, Spain), ESQ and ESQ2 (Esquivias, Madrid, Spain), YUC (Ticul, Yucatán, Mexico), BER (Bercimuel, Segovia, Spain), SEG (Segovia, Spain), TOR (Torrejón el Rubio, Cáceres, Spain), PIC (Pics Crossing, Australia) and GR0-GR4, GR6-GR9 (Pefkaki, W. Macedonia, Greece).

Earlier references to these samples can be found in Table 1. The composition of 18 of these samples was

Table 1. Selected compositional parameters determined by NIR according to Chryssikos et al. (2009) and defined in Equation (1), interplanar distances and NIR peak positions of palygorskite samples in this study.

\begin{tabular}{|c|c|c|c|c|c|c|c|c|c|}
\hline & $y$ & $x(1-y)$ & $(1-x)(1-y)$ & $d_{200}(\AA)$ & $d_{110}(\AA)$ & $\begin{array}{l}(v+\delta) \mathrm{SiO}-\mathrm{H} \\
\quad\left(\mathrm{cm}^{-1}\right)\end{array}$ & $\begin{array}{c}(v+\delta) \mathrm{HO}-\mathrm{H} \\
\text { ambient }\left(\mathrm{cm}^{-1}\right)\end{array}$ & $\begin{array}{c}(v+\delta) \mathrm{HO}^{-\mathrm{H}_{\mathrm{b}}} \text { dry } \\
\left(\mathrm{cm}^{-1}\right)\end{array}$ & References \\
\hline LIL & 0.00 & 0.00 & 1.00 & $6.349(3)$ & $10.464(3)$ & 4577.7 & 5182.1 & 5111.0 & $\begin{array}{l}\text { Suárez et al. (2007), } \\
\quad \text { Chryssikos et al. (2009) }\end{array}$ \\
\hline PAL & 0.00 & 0.00 & 1.00 & $6.375(3)$ & $10.462(3)$ & ) 4577.1 & 5184.8 & 5112.4 & \\
\hline SEG & 0.00 & 0.01 & 0.99 & $6.349(3)$ & $10.482(3)$ & 4577.9 & 5183.7 & 5111.3 & \\
\hline CAS & 0.00 & 0.00 & 1.00 & $6.355(3)$ & $10.417(3)$ & n.a. & 5183.2 & 5111.1 & \\
\hline ATT & 0.08 & 0.11 & 0.81 & $6.421(3)$ & $10.525(3)$ & ) 4575.9 & 5188.6 & 5115.4 & Suárez et al. (2007) \\
\hline TRA & 0.14 & 0.11 & 0.75 & $6.43(3)$ & $10.613(3)$ & ) 4574.7 & 5192.3 & 5115.8 & $\begin{array}{l}\text { Suárez et al. (2007), } \\
\text { Chryssikos et al. (2009) }\end{array}$ \\
\hline ESQ & 0.28 & 0.09 & 0.63 & $6.465(3)$ & $10.584(3)$ & ) 4573.4 & 5193.4 & 5114.9 & $\begin{array}{l}\text { Suárez et al. (2007), } \\
\text { Chryssikos et al. (2009) }\end{array}$ \\
\hline ESQ2 & 0.48 & 0.08 & 0.44 & $6.542(3)$ & $10.700(3)$ & ) 4572.1 & 5198.7 & 5114.3 & Chryssikos et al. (2009) \\
\hline TOR & 0.06 & 0.19 & 0.75 & $6.407(3)$ & $10.461(3)$ & ) 4576.9 & 5187.5 & 5115.2 & $\begin{array}{l}\text { Suárez et al. (2007), } \\
\text { Chryssikos et al. (2009) }\end{array}$ \\
\hline PIC & 0.09 & 0.25 & 0.66 & $6.41(2)$ & $10.46(2)$ & ) 4576.2 & 5189.0 & 5116.3 & Chryssikos et al. (2009) \\
\hline GR0 & 0.08 & 0.33 & 0.59 & $6.43(2)$ & $10.54(2)$ & ) 4574.5 & 5193.4 & 5119.2 & Chryssikos et al. (2009) \\
\hline GR1 & 0.07 & 0.46 & 0.46 & $6.46(2)$ & $10.55(2)$ & ) 4574.2 & 5194.5 & 5121.2 & $\begin{array}{l}\text { Gionis et al. (2006), } \\
\text { Gionis et al. (2007), } \\
\text { Chryssikos et al. (2009) }\end{array}$ \\
\hline GR2 & 0.45 & 0.26 & 0.29 & $6.52(2)$ & $10.67(2)$ & ) 4570.9 & 5200.0 & 5120.8 & $\begin{array}{l}\text { Gionis et al. (2007), } \\
\text { Chryssikos et al. (2009) }\end{array}$ \\
\hline GR3 & 0.15 & 0.51 & 0.34 & $6.47(2)$ & $10.59(2)$ & ) 4572.3 & 5196.6 & 5123.8 & Chryssikos et al. (2009) \\
\hline GR4 & 0.19 & 0.49 & 0.32 & $6.49(2)$ & $10.59(2)$ & ) 4572.0 & 5196.7 & 5123.0 & Chryssikos et al. (2009) \\
\hline GR6 & 0.33 & 0.31 & 0.36 & $6.49(2)$ & $10.59(2)$ & 4570.8 & 5197.1 & 5121.3 & Chryssikos et al. (2009) \\
\hline GR7 & 0.33 & 0.31 & 0.36 & $6.51(2)$ & $10.63(2)$ & ) 4571.2 & 5197.7 & 5122.5 & Chryssikos et al. (2009) \\
\hline
\end{tabular}




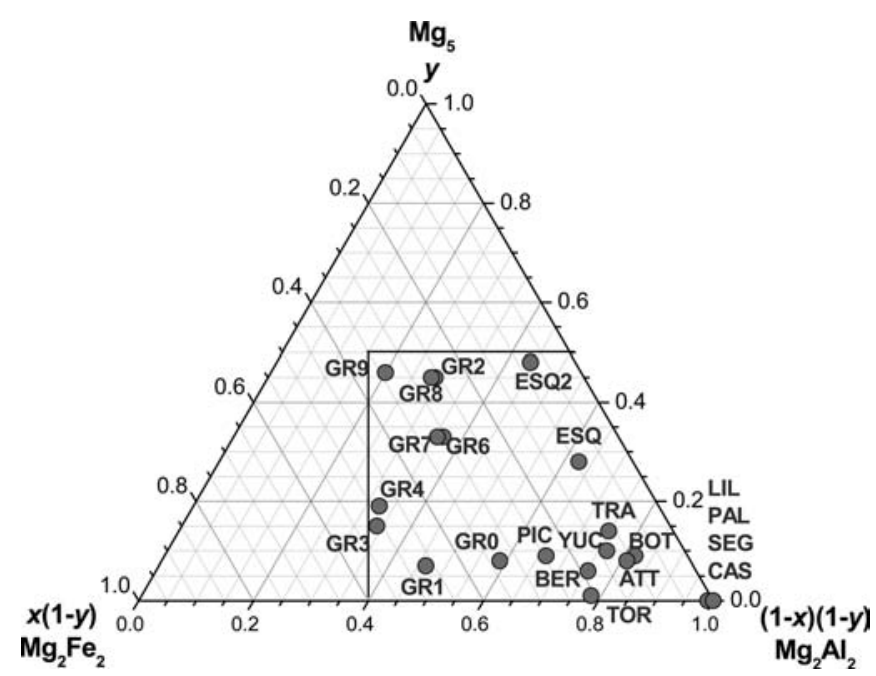

Fig. 3. Octahedral composition of the 22 palygorskite samples in this work, as described by the formula $y \mathrm{Mg}_{5} \mathrm{Si}_{8} \mathrm{O}_{20}(\mathrm{OH})_{2}\left(\mathrm{OH}_{2}\right)_{4}$ $\cdot(1-y)\left[x \mathrm{Mg}_{2} \mathrm{Fe}_{2} \cdot(1-x) \mathrm{Mg}_{2} \mathrm{Al}_{2}\right] \mathrm{Si}_{8} \mathrm{O}_{20}(\mathrm{OH})_{2}\left(\mathrm{OH}_{2}\right)_{4}$ and derived from the analysis of the NIR spectra. For details and comparison with single-particle AEM data see Chryssikos et al. (2009).

determined by AEM and NIR (Chryssikos et al., 2009). The octahedral composition of four samples (PAL, SEG, CAS and ATT) not included in the study of Chryssikos et al. (2009) was measured by the same NIR method. Figure 3 depicts the octahedral composition of the samples expressed in terms of the dioctahedral aluminous, $(1-x)(1-y)$, dioctahedral ferric, $x(1-y)$, and trioctahedral magnesian, $y$, compositional coordinates determined by NIR and defined in Equation (1). Sepiolite from Valdemoro, Madrid, Spain (SepSp-1) is studied for comparison.

\subsection{Spectroscopic and $X$-ray diffraction measurements}

NIR spectra (averages of 200 scans at $4 \mathrm{~cm}^{-1}$ resolution, Blackman-Harris 3-term apodization and zero-filling factor of two) were measured on a Fourier transform instrument (Vector $22 \mathrm{~N}$ by Bruker Optics) equipped with an integrating sphere accessory. The second derivative of the NIR absorption was computed from the smoothed spectra employing the Savitzky-Golay algorithm with 13point windowing. In addition to ambient NIR measurements, the samples were dried and measured in situ by a combination of mild heating at $c a .50{ }^{\circ} \mathrm{C}$ and $\mathrm{P}_{2} \mathrm{O}_{5}$ desiccation, i.e. conditions causing the progressive removal of surface and zeolitic $\mathrm{H}_{2} \mathrm{O}$ (Gionis et al., 2006).

Palygorskite X-ray diffractograms were measured by high-resolution powder XRD at beam line BM25A of the Spanish CRG at the European Synchrotron Radiation Facility. Four new samples (PAL, SEG, CAS and ESQ2) complement the collection (LIL, BER, YUC, BOT, TOR, ATT, TRA and ESQ) previously studied by the same technique (Suárez et al., 2007). Synchrotron radiation allows for an instrumental contribution to the peak Full Width at Half Maximum (FWHM) down to $c a .0 .003^{\circ}$ with high precision and reproducibility. Values for $d$ are obtained from the synchrotron diffractograms by fitting the corresponding hkl peak with a pseudo-Voight function with an accuracy of $0.003 \AA$. The remaining samples (PIC and GR3-9) were measured by laboratory XRD (X'TRA 17 by Thermo ARL) equipped with a Peltier detector and employing $\mathrm{CuK} \alpha$ radiation at $45 \mathrm{kV}$ and $40 \mathrm{~mA}$. With divergence and receiving slits at 0.4 and $0.5 \mathrm{~mm}$, respectively, scans from $2-70^{\circ} 2 \theta$ and counting time of $10 \mathrm{~s}$ per step of $0.02^{\circ}$, these measurements determine $d$-values with an accuracy of $0.02 \AA$. The patterns of samples GR 1 and GR2 have been reported by Gionis et al. (2007). All samples studied by XRD are identified as palygorskite with $d_{110}$ in the 10.4-10.7 $\AA$ range and exhibit no trace of the $c a$. $12 \AA$ peak of sepiolite.

\section{Results}

\subsection{Octahedral composition and the dimensions of the unit cell}

The parameter $a$ of orthorhombic palygorskite ( $a \sin \beta$ for the monoclinic form, Christ et al., 1969) is derived from the position of the 200 reflection at $c a .13^{\circ} 2 \theta \mathrm{CuK} \alpha$. The parameter $b$ can be evaluated from the poorly resolved 040 reflection $\left(c a .19^{\circ} 2 \theta \mathrm{CuK} \alpha\right)$ or by using the 110 (ca. $8.5^{\circ}$ $2 \theta \mathrm{CuK} \alpha)$ and 200 reflections, but $c(c a .5 .25 \AA)$ cannot be obtained from the diffractograms, owing to the orientation of the palygorskite fibers along [001]. Sepiolite exhibits 200 (overlapping with a 040 contribution) and 060 reflections in the same ranges as the 200 and 040 reflections of palygorskite, respectively (Brindley \& Brown, 1980). According to Post \& Crawford (2007), $d_{200}$ for palygorskite is in the range 6.31-6.43 $\mathrm{A}$, with no obvious correlation with octahedral composition. Suárez et al. (2007) reported palygorskites with $d_{200}$ in the range 6.35-6.47 $\AA$ and found a linear relationship $\left(R^{2}=0.95\right)$ between the number of octahedral $\mathrm{Al}$ ions per $8 \mathrm{Si}$ and $d_{200}$, [ $\left.{ }^{\mathrm{VI}} \mathrm{Al}\right]$ 49.16-7.44 $d_{200}$. This relationship extrapolates to an ideal magnesian palygorskite with $d_{200}=6.61 \AA$, i.e. close to the $d_{200}$ range of sepiolite. This extrapolation was of limited precision owing to the relatively narrow compositional range of the collection studied $(y<0.3$ and $x<0.2$ according to Equation (1)) and is revisited here with additional samples of greater composition range. Besides octahedral composition, $d_{200}$ is also affected by zeolitic $\mathrm{H}_{2} \mathrm{O}$ content (Post \& Crawford, 2007; Post \& Heaney, 2008). To isolate the effect of octahedral substitution from that of zeolitic $\mathrm{H}_{2} \mathrm{O}$ content, all unit cell data in this study refer to the ambient $(\mathrm{RH} \approx 40 \%)$ "zeolitically wet" state. The effect of composition on the unit cell dimensions of palygorskite equilibrated at ambient temperature over $\mathrm{P}_{2} \mathrm{O}_{5}$ ("zeolitically dry" state) is not considered in this paper.

There are four aluminous dioctahedral samples $(x \rightarrow 0$, $y \rightarrow 0$ ) in this set (LIL, PAL, SEG, CAS) and these have $d_{200}$ $=6.36 \pm 0.02 \AA$, in good agreement with the reported $a / 2$ or $(a \sin \beta) / 2$ dimensions of palygorskites with similar composition (Chiari et al., 2003; Giustetto \& Chiari, 2004; Post 


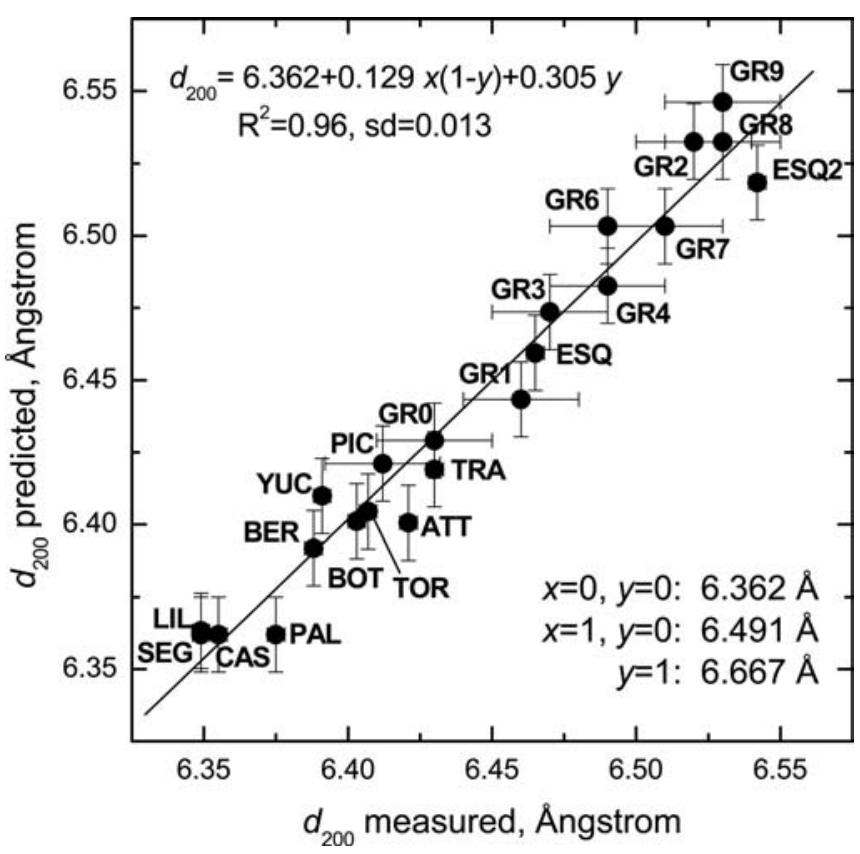

Fig. 4. Palygorskite $d_{200}$ predicted by Equation (2). Line is least squares fit.

$\&$ Heaney, 2008). The largest $d_{200}$ values observed are $c a$. $3 \%$ higher $\left(d_{200}=6.54 \pm 0.01\right.$ A for ESQ2, GR8, GR9). Values intermediate between these limits can be found among dioctahedral samples with significant $\mathrm{Fe}^{\mathrm{III}}$ for $\mathrm{Al}$ substitution, or among Fe-poor samples with a high trioctahedral fraction (e.g., $d_{200}=6.46 \pm 0.01 \AA$ for GR1, ESQ). The effect of $\mathrm{Fe}^{\mathrm{III}}$ and $\mathrm{Mg}$ in expanding $d_{200}$ can be determined by a multiple linear regression analysis with $x(1-y)$ and $y$ as independent variables. These variables correspond to the fraction of ideal dioctahedral ferric and trioctahedral magnesian palygorskite of Equation (1), $\mathrm{Mg}_{2} \mathrm{Fe}_{2} \mathrm{Si}_{8} \mathrm{O}_{20}(\mathrm{OH})_{2}\left(\mathrm{OH}_{2}\right)_{4}$ and $\mathrm{Mg}_{5} \mathrm{Si}_{8} \mathrm{O}_{20}(\mathrm{OH})_{2}\left(\mathrm{OH}_{2}\right)_{4}$, respectively. The resulting expression for $d_{200}$ is of high predictive value: $R^{2}=0.96, \sigma=0.013 \AA$ (Fig. 4):

$$
\begin{aligned}
d_{200}(\AA)= & (6.362 \pm 0.005)+(0.129 \pm 0.019) x(1-\mathrm{y}) \\
& +(0.305 \pm 0.018) y
\end{aligned}
$$

This equation is based on $x, y$ values determined by NIR on the 22 samples studied (Table 1). However, an almost equally strong regression $\left(R^{2}=0.92, \sigma=0.018 \AA\right)$ is obtained on the basis of the AEM data available for the 18 samples in Chryssikos et al. (2009). Equation (2) updates the model of Suárez et al. (2007) over broader ranges of octahedral substitution and $d_{200}(6.36-6.54 \AA)$. Ideal dioctahedral aluminous, $\mathrm{Mg}_{2} \mathrm{Al}_{2} \mathrm{Si}_{8} \mathrm{O}_{20}(\mathrm{OH})_{2}\left(\mathrm{OH}_{2}\right)_{4}$, and ferric, $\mathrm{Mg}_{2} \mathrm{Fe}_{2} \mathrm{Si}_{8} \mathrm{O}_{20}(\mathrm{OH})_{2}\left(\mathrm{OH}_{2}\right)_{4}$, palygorskites are predicted to have $d_{200}$ spacings of 6.362 and $6.491 \pm 0.013 \AA$, respectively. In dioctahedral palygorskites with intermediate $\mathrm{Fe}^{\mathrm{III}}$ for Al substitution, $\left.x \mathrm{Mg}_{2} \mathrm{Fe}_{2} \cdot(1-x) \mathrm{Mg}_{2} \mathrm{Al}_{2} \mathrm{Si}_{8} \mathrm{O}_{20} \mathrm{OH}\right)_{2}$ $\left(\mathrm{OH}_{2}\right)_{4}, d_{200}$ varies linearly with $x$ between these limits. It is emphasized that dioctahedral palygorskites are Al-Fe solid solutions and not weighted mixtures of the $x=0$ and $x=1$ end-members (Gionis et al., 2006, 2007).
The effect of trioctahedral fraction, $y$, in expanding $d_{200}$ is about twice as large as that of the dioctahedral ferric fraction, as expected from the larger ionic radius of $\mathrm{Mg}$ and the occupation of the M1 octahedral site. With all cautions that apply to the physical meaning of extrapolations over composition gaps that may involve structural discontinuities, Equation (2) predicts $d_{200}=6.667 \pm 0.013 \AA$ for a $y$ $=1$ palygorskite, $\mathrm{Mg}_{5} \mathrm{Si}_{8} \mathrm{O}_{20}(\mathrm{OH})_{2}\left(\mathrm{OH}_{2}\right)_{4}$. Remarkably, this value is in the center of the 6.63-6.72 $\AA d_{200}$ range of sepiolite (Post \& Crawford, 2007) and coincides exactly with the $6.67 \AA d$-value measured for SepSp-1.

A similar regression analysis of $d_{110}$ (data in Table 1, graph not shown) yields

$$
\begin{aligned}
d_{110}(\AA)= & (10.46 \pm 0.01)+(0.10 \pm 0.05) x(1-\mathrm{y}) \\
& +(0.41 \pm 0.05) y
\end{aligned}
$$

This fit $\left(R^{2}=0.83, \sigma=0.04 \AA\right)$ is inferior to Equation (2) suggesting a poorer correlation between composition and $b$. An additional source of incertitude of $d_{110}$ is due to the fact that this reflection, although very intense, is at low $2 \theta$ and is usually highly asymmetric. Therefore, texture, crystallinity and particle size have a stronger effect on $d_{110}$ than $d_{200}$. Equation (3) extrapolates to $\mathrm{Mg}_{5} \mathrm{Si}_{8} \mathrm{O}_{20}(\mathrm{OH})_{2}\left(\mathrm{OH}_{2}\right)_{4}$ at $d_{110} \approx 10.9 \AA$, a value that is about $1.2 \AA$ less than the $d_{110}$ spacing of SepSp-1 and other sepiolites (Post \& Crawford, 2007).

\subsection{Monitoring the loss of zeolitic $\mathrm{H}_{2} \mathrm{O}$ by NIR spectroscopy}

All samples (Table 1) were monitored by NIR spectroscopy and representative dehydration sequences are shown for SEG, YUC, ESQ and GR2 in comparison to SepSp-1 (Fig. 5). Based on the assignments of Gionis et al. (2006), the $\mathrm{M} 2 \mathrm{M} 2 \mathrm{OH}$ overtone triplet of $\mathrm{AlAlOH}, \mathrm{AlFeOH}$ and $\mathrm{FeFeOH}$ units in dioctahedral palygorskite $(7056,6994$, $6928 \mathrm{~cm}^{-1}$ shifting by $c a .+20 \mathrm{~cm}^{-1}$ upon dehydration), is clearly identified. The position of these overtones and their response to the loss of zeolitic $\mathrm{H}_{2} \mathrm{O}$ are independent of composition, whereas the relative intensity of the individual components is solely governed by $x$ (Chryssikos et al., 2009). Trioctahedral ribbons in palygorskite are identified by their $\mathrm{Mg}_{3} \mathrm{OH}$ overtone at $7214 \mathrm{~cm}^{-1}$ shifting to 7192 $\mathrm{cm}^{-1}\left(-22 \mathrm{~cm}^{-1}\right)$ upon dehydration (Gionis et al., 2007). Except for its intensity that scales with $y$, this spectroscopic fingerprint is identical in all palygorskite samples investigated. This suggests that the trioctahedral entities encountered in palygorskite are of a single well-defined type, regardless of octahedral composition. Notably, these cannot be distinguished spectroscopically from those of sepiolite, which is a three-chain ribbon mineral (Fig. 5).

The early steps of the zeolitic dehydration of palygorskite and sepiolite are paralleled by the loss of $\mathrm{H}_{2} \mathrm{O}$ adsorbed on the external surface of the particles. This process produces additional bands attributed to $\mathrm{SiOH}$ species (Ahlrichs et al., 1975; Serna et al., 1977). These species terminate the exposed edges of the ribbons and are relatively abundant owing to the lath-like morphology 


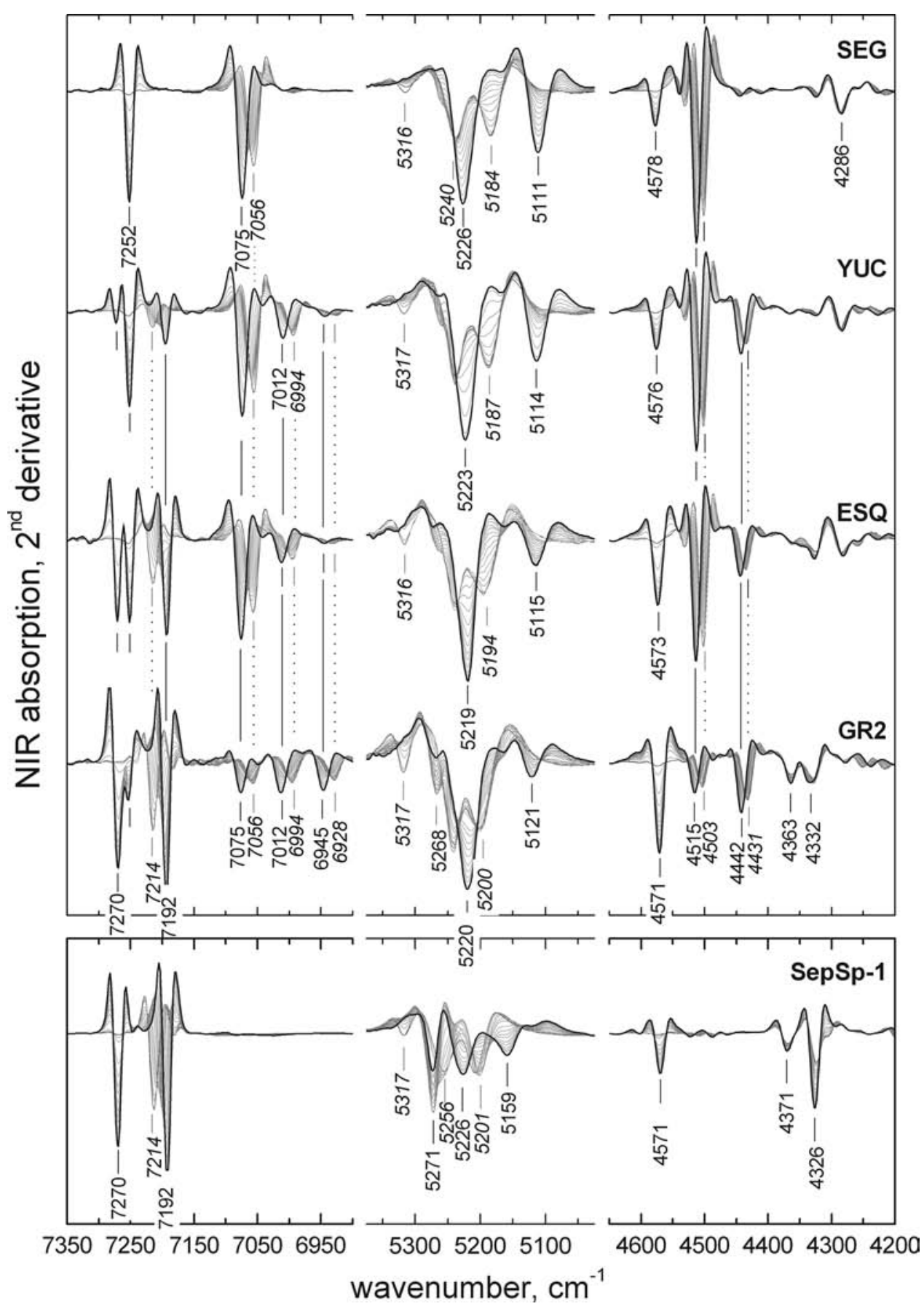

Fig. 5. NIR monitoring of the zeolitic dehydration of palygorskites SEG, YUC, ESQ and GR2 and sepiolite SepSp-1, over the 2nd derivative $\mathrm{OH}$ overtone (left), $\mathrm{H}_{2} \mathrm{O}$ combination $(\times 2$, middle) and $\mathrm{OH}$ combination (right) wavenumber ranges. Traces in black mark the zeolitically dry end-point of each sequence.

of palygorskite and sepiolite. In the 2nd derivative NIR spectra of palygorskite samples, these surface $\mathrm{SiOH}$ groups (shown schematically as open circles in Fig. 2) exhibit a sharp overtone mode at $7252 \mathrm{~cm}^{-1}$, with a $2-3 \mathrm{~cm}^{-1}$ dependence on $x$ (Gionis et al., 2006). Increasing the trioctahedral character of palygorskite, e.g. from SEG ( $y$ $=0)$, to GR2 $(y=0.45)$ results in the decrease of the relative intensity of the $7252 \mathrm{~cm}^{-1}$ overtone and the appearance of a new band at $7270 \mathrm{~cm}^{-1}$ with increasing intensity (Fig. 5). Clearly, the latter is related to the exposed edges of the trioctahedral ribbons of palygorskite (filled circles, Fig. 2). Interestingly, Fig. 5 demonstrates that these edges cannot be distinguished from those of SepSp-1, also active at $7270 \mathrm{~cm}^{-1}$.

Lastly, the NIR spectra are sensitive to the presence and bonding of $\mathrm{H}_{2} \mathrm{O}$ in the tunnels (Fig. 5). The corresponding 2nd derivative spectra of ambient ideal palygorskite reveal three bands at ca. 5317,5240 and $5190 \mathrm{~cm}^{-1}$ (Gionis et al., 
2006). The $5317 \mathrm{~cm}^{-1}$ band is assigned to $\mathrm{H}_{2} \mathrm{O}$ adsorbed on the surface $\mathrm{SiOH}$ groups and is vanishing upon mild dehydration. The remaining two bands of the ambient $(v+\delta)$ combination spectrum and especially the low wavenumber component at $c a .5190 \mathrm{~cm}^{-1}$ arise from the interaction between zeolitic $\mathrm{H}_{2} \mathrm{O}$ and coordinated $\mathrm{OH}_{2}$. As zeolitic $\mathrm{H}_{2} \mathrm{O}$ is removed, coordinated $\mathrm{OH}_{2}$ rearrange and interact asymmetrically with the Si-O-Si linkages of adjacent ribbons. By doing so, they lower their symmetry from $\mathrm{C}_{2 \mathrm{v}}$ to $\mathrm{C}_{\mathrm{s}}$ (Prost, 1975; Serna et al., 1977) and produce two sharp NIR combination modes at $c a .5220$ and $5120 \mathrm{~cm}^{-1}$ (Gionis et al., 2006). Overall, the loss of zeolitic $\mathrm{H}_{2} \mathrm{O}$ of palygorskite involves a simple transition as the combination spectrum at ambient conditions diminishes and gives place to that of the zeolitically dry state.

This is not the case with sepiolite SepSp-1. Although the $\mathrm{H}_{2} \mathrm{O}$ combination spectrum of sepiolite is analogous to that of palygorskite in both the ambient and dry states (with triplet and doublet envelopes peaking at 5317, 5256 and 5201 and 5226, $5159 \mathrm{~cm}^{-1}$, respectively), the transition between these states involves a well-defined intermediate not observed in palygorskite. This intermediate state is identified mainly by a sharp $(v+\delta) \mathrm{H}_{2} \mathrm{O}$ band at $c a .5270$ $\mathrm{cm}^{-1}$ which initially grows and then decreases in intensity upon drying (Fig. 5). This band signals the presence of partially filled tunnels of sepiolite and is therefore associated with a localized $\mathrm{H}$-bonding motif between $\mathrm{Mg}$-coordinated $\mathrm{OH}_{2}$ and remaining zeolitic $\mathrm{H}_{2} \mathrm{O}$. Interestingly, the same intermediate state is observed in the NIR spectra of Mg-rich palygorskites upon drying (Fig. 5).

Similarly, in the spectra of dry palygorskite the $\mathrm{H}_{2} \mathrm{O}$ combination mode at $c a$. $5110-5120 \mathrm{~cm}^{-1}$ is exclusively related to the dioctahedral component: Its intensity decreases with increasing $y$, it is absent from SepSp-1 and its peak wavenumber depends exclusively on $x$ :

$$
\begin{aligned}
(v+\delta) \mathrm{HO}-\mathrm{H}_{\mathrm{b}}\left(\mathrm{cm}^{-1}\right)= & 5111.7+19.8 x \\
& \left(R^{2}=0.97, \sigma=0.8\right)
\end{aligned}
$$

This increase of the $(v+\delta) \mathrm{HO}-\mathrm{H}_{\mathrm{b}}$ wavenumber with $x$ indicates the weakening of the $\mathrm{H}$-bonding interactions between coordinated $\mathrm{OH}_{2}$ and the neighboring inter-ribbon Si-O-Si linkage (Prost, 1975; Serna et al., 1977). The trend is consistent with the parallel increase of $d_{200}$ which, in the case of ideal dioctahedral palygorskite, was found to depend solely on the fraction of $\mathrm{Fe}^{\mathrm{III}}$ in $\mathrm{M} 2$ sites (Equations (1) and (2), Fig. 6).

\section{Discussion}

The above analysis has identified a number of NIR spectroscopic indicators for palygorskite and sepiolite subjected to loss of zeolitic $\mathrm{H}_{2} \mathrm{O}$. These indicators "report" from three specific locations of the structure:

(1) the ribbons (various types of $\mathrm{M}_{2} \mathrm{O}-\mathrm{H}$ and $\mathrm{M}_{3} \mathrm{O}-\mathrm{H}$ species),

(2) the tunnels (coordinated $\mathrm{OH}_{2}$ and zeolitic $\mathrm{H}_{2} \mathrm{O}$ ), and

(3) the external surface of the particles (terminal $\mathrm{SiOH}$ ).
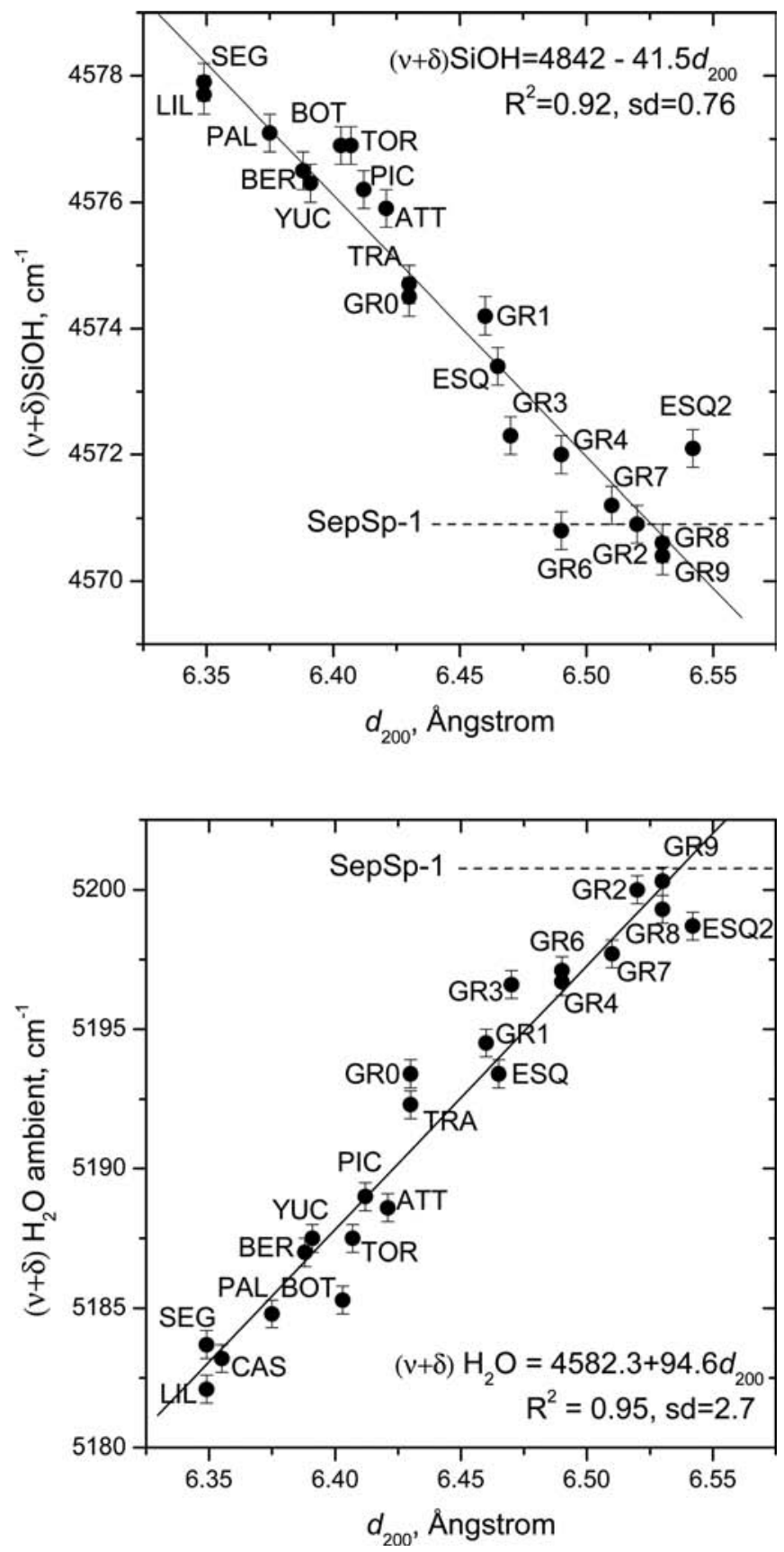

Fig. 6. Dependence of the $(v+\delta) \mathrm{SiOH}$ wavenumber of dry palygorskite (upper), and the $(v+\delta) \mathrm{H}_{2} \mathrm{O}$ wavenumber of ambient palygorskite (lower) on $d_{200}$. Solid lines are least square fits. Dashed lines mark the corresponding values for SepSp-1.

All these indicators distinguish the dioctahedral entities of palygorskite from their trioctahedral counterparts. The spectrum and structure of the dioctahedral entities vary in a manner determined uniquely by the substitution of Al by $\mathrm{Fe}^{\mathrm{III}}$ in M2 sites. In contrast, only one type of trioctahedral entity is observed in the palygorskite samples investigated. This trioctahedral entity, common to all palygorskite samples investigated, is spectroscopically (hence structurally) identical to sepiolite. 
Other features of the NIR spectra cannot distinguish between the two types of entities in palygorskite. As typically observed with low-resolution indicators, these features exhibit a pseudo-one mode behavior and shift smoothly from the aluminous dioctahedral palygorskite to the sepiolite limit values as $y$ spans the $0-0.5$ range of Equation (1). Examples of this type are the $(v+\delta) \mathrm{H}_{2} \mathrm{O}$ mode of ambient palygorskite at $c a .5190 \mathrm{~cm}^{-1}(\mathrm{SEG}=$ $5184 \mathrm{~cm}^{-1}, \mathrm{GR} 2=5200 \mathrm{~cm}^{-1}, \mathrm{SepSp}-1=5201 \mathrm{~cm}^{-1}$, Table 1$)$, or the $(v+\delta) \mathrm{SiOH}$ mode of zeolitically dry palygorskite $\left(\mathrm{SEG}=4578 \mathrm{~cm}^{-1}\right.$, GR2 $=$ SepSp-1 $=4571$ $\left.\mathrm{cm}^{-1}\right)$. Both vary linearly with $d_{200}$ over the $6.35-6.55 \AA$ range (hence depend on both $x(1-y)$ and $y$, Equation (2)) and reach the values expected from sepiolite at $y \approx 0.5$ (Fig. 6). According to these indicators, any hypothetical sample with $0.5<y<1$ would appear identical to sepiolite.

The assignment of the trioctahedral vibrational signature in palygorskite to sepiolite-type ribbons, $\mathrm{Mg}_{8} \mathrm{Si}_{12} \mathrm{O}_{30}(\mathrm{OH})_{4}\left(\mathrm{OH}_{2}\right)_{4}$, accounts fully for the observed spectra, their dependence on composition and their systematic changes upon loss of zeolitic $\mathrm{H}_{2} \mathrm{O}$. No spectroscopic evidence is left unassigned to hint the presence of trioctahedral two-chain palygorskite ribbons, $\mathrm{Mg}_{5} \mathrm{Si}_{8} \mathrm{O}_{20}(\mathrm{OH})_{2}\left(\mathrm{OH}_{2}\right)_{4}$. Given the finenesse of the spectroscopic indicators employed, the hypothesis that the two types of trioctahedral ribbons are indistinguishable from each other is not probable. Thus, Mg-rich palygorskite as observed by NIR is a polysomatic mineral consisting of palygorskite (dioctahedral with variable $\mathrm{Fe}^{\mathrm{III}}$ for $\mathrm{Al}$ substitution) and sepiolite [001] ribbons, as in Fig. 7. Polysomatism is shown as random although connectivity constraints impose either stacking along 100 , or the formation of dislocations and tunnel defects.

Similar silicate chain-width polysomatism in TOT minerals, ordered or disordered in the $b$ direction, has been extensively studied in biopyriboles (Veblen \& Buseck, 1979; Welch et al., 1992), and palygorskite/sepiolite structures have been included as special limiting cases in the polysomatic model of Zoltai (1981). More relevant in the context of this study is the polysomatic description of kalifersite, a member of the palygorskite/sepiolite group with regularly alternating palygorskite and sepiolite-like [001] ribbons, $P_{1} S_{1}$ (Ferraris et al., 1998; Ferraris \& Gula, 2005). Krekeler et al. (2005) and Krekeler \& Guggenheim (2007) have provided HRTEM evidence for chain-width polysomatism in a palygorskite sample from the Hawthorne formation, as well as for the presence of tunnel defects in a sepiolite from Finland and a yofortierite from Quebec. Martin Vivaldi \& Linares Gonzales (1960) described a sample from Almería, Spain, as a random intergrowth of sepiolite and palygorskite. However, to our knowledge, this is the first time that Mg-rich palygorskite samples from many different localities are generally described as members of a polysomatic series involving (dioctahedral) palygorskite and sepiolite with formula:

$$
\begin{gathered}
y^{\prime} \mathrm{Mg}_{8} \mathrm{Si}_{12} \mathrm{O}_{30}(\mathrm{OH})_{4}\left(\mathrm{OH}_{2}\right)_{4} \cdot\left(1-\mathrm{y}^{\prime}\right)\left[x^{\prime} \mathrm{Mg}_{2} \mathrm{Fe}_{2} .\right. \\
\left.\left(1-\mathrm{x}^{\prime}\right) \mathrm{Mg}_{2} \mathrm{Al}_{2}\right] \mathrm{Si}_{8} \mathrm{O}_{20}(\mathrm{OH})_{2}\left(\mathrm{OH}_{2}\right)_{4}
\end{gathered}
$$
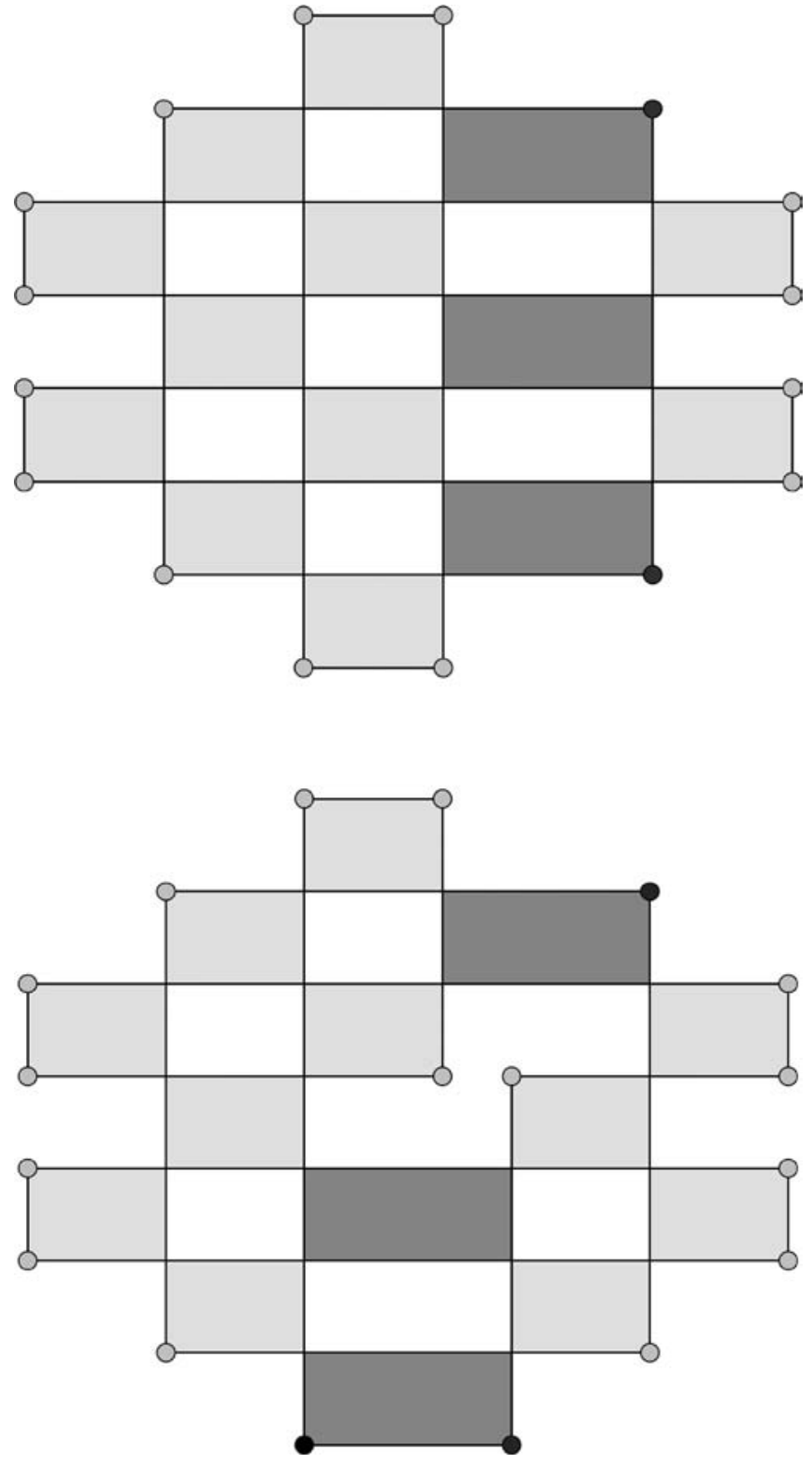

Fig. 7. Polysomatic model for Mg-rich palygorskite with $35 \%$ trioctahedral character consisting of sepiolite ribbons (dark grey) intergrown amidst dioctahedral palygorskitic ribbons (grey). Ordering along $b$ (upper) or dislocations (lower) are imposed by the geometric constrains.

where, $y^{\prime}$ and $\left(1-y^{\prime}\right)$ represent the fractions of sepiolite and palygorskite ribbons, respectively, and $x^{\prime}$ is the fraction of $\mathrm{Fe}^{\mathrm{III}}$ in the M2 sites of palygorskite. This formula can be extended to accommodate possible substitutions of $\mathrm{Mg}$ in sepiolite by other divalent cations $\mathrm{M}^{\mathrm{II}}$ (e.g., $\mathrm{Fe}^{\mathrm{II}}$ or Ni), if these substitutions are evident via the characteristic $\left(\mathrm{Mg}_{3-z} \mathrm{M}_{z}^{\mathrm{II}}, z=0-3\right) \mathrm{OH}$ overtone quadruplet (Clark et al., 1990; Petit et al., 2004). The correlation between NIR and AEM data, (Chryssikos et al., 2009), which is incorporated in the calculation of $x$ and $y$ (Equation (1)) remains compatible with Equation (5) and the parameters $x^{\prime}$ and $y^{\prime}$. In this case, $x$ and $x^{\prime}$ are identical because they are 
confined to the dioctahedral portion of the formulae. Also, $y /(1-y)=2 y^{\prime} /\left(1-y^{\prime}\right)$ because sepiolite has twice as many structural $\mathrm{OH}$ per unit cell than palygorskite, hence $y^{\prime}=y /$ $(2-y)$. Therefore, the trioctahedral fraction which, if expressed in terms of magnesian palygorskite ribbons, is in the range $0 \leq y \leq 0.5$ (Equation (1)), yields a narrower range when expressed as sepiolite in Equation (5), $0 \leq y^{\prime} \leq$ 0.33 .

Despite strong evidence from vibrational spectroscopy, the proposed palygorskite-sepiolite polysomatic model needs to be tested by additional experimental techniques. Techniques sensitive to the structure of the tetrahedral sheet such as ${ }^{29} \mathrm{Si}$ NMR have been used to distinguish two- from three-chain width polysomes in biopyriboles (Welch et al., 1992). Visualization of the polysomes by HRTEM is the most direct approach (Chen et al., 2008) and requires the study of a number of beam-sensitive particles from each sample. In combination to HRTEM, pattern simulation techniques can be used to in interpret the $\mathrm{X}$-ray diffraction pattern of the Mg-rich samples as in the work of Kogure et al. (2006). Finally, studies should be extended to palygorskite/sepiolite samples bridging the range between the most magnesian palygorskite reported in this work and SepSp-1.

Acknowledgements: ESRF is acknowledged for beam time at the Spline and expert support from their staff. Marcello Mellini and Victor Drits are thanked for the thorough refereeing of this manuscript. Earlier comments on this work by Steve Guggenheim and Emilio Galán are also appreciated. The authors are grateful to the Spanish CICYT for financial support (Project CGL2009-10764). Research at NHRF was funded by Geohellas S.A.

\section{References}

Ahlrichs, P.A., Serna, C., Serratosa, J.M. (1975): Structural hydroxyls in sepiolites. Clays Clay Miner., 23, 119-124.

Artioli, G., Galli, E., Burattini, E., Cappuccio, G., Simeoni, S. (1994): Palygorskite from Bolca, Italy - a characterization by high-resolution synchrotron-radiation powder diffraction and computer modelling. Neues Jahrb. Mineral. Monatsh., 5, 217-229.

Bradley, W.F. (1940): The structural scheme of attapulgite. Am. Mineral., 25, 405-411.

Brauner, K. \& Preisinger, A. (1956): Struktur und entstehung des sepioliths. Tscher. Mineral. Petrogr. Mitteil., 6, 120-140.

Brindley, G.W. \& Brown, G. (1980): Crystal structures of clay minerals and their X-ray identification. Monograph, 5, Mineralogical Society, London, 104-115.

Cai, Y., Xue, J., Polya, D.A. (2007): A Fourier transform infrared spectroscopic study of Mg-rich, Mg-poor, and acid leached palygorskites. Spectrochim. Acta Part A, 66, 282-288.

Chahi, A., Petit, S., Decarreau, A. (2002): Infrared evidence of dioctahedral - trioctahedral site occupancy in palygorskite. Clays Clay Miner., 50, 306-313.
Chen, T., Wang, H., Zhang, X., Zheng, N. (2008): SAED and HRTEM investigation of palygorskite. Acta Geol. Sin., 82, 385-391.

Chiari, G., Giustetto, R., Ricchiardi, G. (2003): Crystal structure refinement of palygorskite and Maya Blue from molecular modeling and powder synchrotron diffraction. Eur. J. Mineral., 15, 21-33.

Christ, C.L., Hathaway, J.C., Hostler, P.B., Shepard, A.O. (1969): Palygorskite: new X-ray data. Am. Mineral., 54, 198-205.

Chryssikos, G.D., Gionis, V., Kacandes, G.H., Stathopoulou, E.T., Suárez, M., García-Romero, E., Sánchez del Río, M. (2009): Octahedral cation distribution in palygorskite. Am. Mineral., 94, 200-204.

Clark, R.N., King, T.V.V., Klejwa, M., Swayze, G.A., Vergo, N. (1990): High spectral resolution reflectance spectroscopy of minerals. J. Geophys. Res., 95, 12653-12680.

Drits, V.A. \& Aleksandrova, V.A. (1966): The crystallochemical nature of palygorskites. Zap. Vses. Miner. Obshch., 95, 551-560.

Drits, V.A. \& Sokolova, G.V. (1971): Structure of palygorskite. Sov. Phys. Crystallogr., 16, 183-185.

Ferraris, G. \& Gula, A. (2005): Polysomatic aspects of microporous minerals - heterophyllosilicates, palysepioles and rhodesiterelated structures. in "Microporous and Mesoporous Phases", G. Ferraris \& S. Merlino, eds. Rev. Mineral. Geochem., 57, Mineralogical Society of America, Chantilly, VA, and the Geochemical Society, Washington, DC, 69-104.

Ferraris, G., Khomyakov, A.P., Belluso, E., Soboleva, S.V. (1998): Kalifersite, a new alkaline silicate from Kola Peninsula (Russia), based on a palygorskite-sepiolite polysomatic series. Eur. J. Mineral., 10, 865-874.

Galán, E. \& Carretero, I. (1999): A new approach to compositional limits for sepiolite and palygorskite. Clays Clay Miner., 47, 399-409.

García-Romero, E. \& Suárez, M. (2010): On the chemical composition of sepiolite and palygorskite. Clays Clay Miner., 58, 1-20.

García-Romero, E., Suárez, M., Bustillo, M.A. (2004): Characteristics of a Mg-palygorskite in Miocene rocks (Madrid Basin, Spain). Clays Clay Miner., 52, 486-496.

Gionis, V., Kacandes, G.H., Kastritis, I.D., Chryssikos, G.D. (2006): On the structure of palygorskite by mid- and near-infrared spectroscopy. Am. Mineral., 91, 1125-1133.

$-, \ldots,-,-(2007)$ : Combined near-infrared and X-ray diffraction investigation of the octahedral sheet composition of palygorskite. Clays Clay Miner., 55, 543-553.

Giustetto, R. \& Chiari, G. (2004): Crystal structure refinement of palygorskite from neutron powder diffraction. Eur. J. Mineral., 16, 521-532.

Gómez-Romero, P. \& Sánchez, C. (2005): Hybrid materials. Functional properties. From Maya Blue to $21^{\text {st }}$ century materials. New J. Chem., 29, 57-58.

Güven, N., D’ Espinose de la Caillerie, J.-B., Fripiat, J.J. (1992): The coordination of aluminous ions in the palygorskite structure. Clays Clay Miner., 40, 457-461.

Kogure, T., Kameda, J., Matsui, T., Miyawaki, R. (2006): Stacking structure in disordered talc: interpretation of its X-ray diffraction pattern by using pattern simulation and high-resolution transmission microscopy. Am. Mineral., 91, 1363-1370.

Krekeler, M.P.S. \& Guggenheim, S. (2007): Defects in microstructure in palygorskite-sepiolite minerals: a transmission electron microscopy (TEM) study. Appl. Clay Sci., 39, 90-105. 
Krekeler, M.P.S., Hammerly, E., Rakovan, J., Guggenheim, S. (2005): Microscopy studies of the palygorskite-to-smectite transformation. Clays Clay Miner., 53, 92-99.

Martin Vivaldi, J.L., \& Linares Gonzales, J. (1960): A random intergrowth of sepiolite and palygorskite. Clays Clay Miner., 9, 592-602.

Paquet, H., Duplay, J., Valleron-Blanc, M.M., Millot, G. (1987): Octahedral composition of individual particles in smectite-palygorskite and smectite-sepiolite assemblages. in Proceedings of the International Clay Conference, L.G. Schultz, H. van Olphen, F.A. Mumpton, eds. The Clay Minerals Society, Bloomington, IN, 73-77.

Perrault, G., Harvey, Y., Pertsowsky, R. (1975): La yofortierite, un nouveau silicate hydraté de manganèse de St-Hilaire, P.Q. Can. Mineral., 13, 68-74.

Petit, S., Martin, F., Wiewiora, A., De Parseval, P., Decarreau, A. (2004): Crystal-chemistry of talc: a near infrared (NIR) spectroscopy study. Am. Mineral., 80, 319-326.

Pluth, J.J., Smith, J.V., Pushcharovsky, D.Y., Semenov, E.I., Bram, A., Riekel, C., Weber, H.-P., Broach, R.W. (1997): Third-generation synchrotron $\mathrm{X}$-ray diffraction of $6-\mu \mathrm{m}$ crystal of raite, $\approx \mathrm{Na}_{3} \mathrm{Mn}_{3} \mathrm{Ti}_{0.25} \mathrm{Si}_{8} \mathrm{O}_{20}(\mathrm{OH})_{2} .10 \mathrm{H}_{2} \mathrm{O}$, opens up new chemistry and physics of low-temperature minerals. Proc. Nat. Acad. Sci. USA, 94, 12263-12267.

Post, J.E. \& Heaney, P.J. (2008): Synchrotron powder X-ray diffraction study of the structure and dehydration behavior of palygorskite. Am. Mineral., 93, 667-675.

Post, J.L. \& Crawford, S. (2007): Varied forms of palygorskite and sepiolite from different geologic systems. Appl. Clay Sci., 36, 232-244.
Post, J.E., Bish, D.L., Heaney, P.J. (2007): Synchrotron powder Xray diffraction study of the structure and dehydration behavior of sepiolite. Am. Mineral., 92, 91-97.

Prost, R. (1975): Etude de l' hydratation des argiles: interactions eaumineral et mécanisme de la rétention de l' eau. $\mathrm{PhD}$ thesis, Université Pierre et Marie Curie, Paris VI.

Serna, C., VanScoyoc, G.E., Ahlrichs, J.L. (1977): Hydroxyl groups and water in palygorskite. Am. Mineral., 62, 784-792.

Singer, A. (1989): Palygorskite and sepiolite group minerals. in "Minerals in Soil Environments", J.B. Dixon \& S.B. Weed, eds., SSSA Book Series, 1, Soil Science Society of America, Madison, WI, 829-872.

Suárez, M., García-Romero, E., Sánchez del Río, M., Martinetto, P., Dooryhée, E. (2007): The effect of the octahedral cations on the dimensions of the palygorskite cell. Clay Miner., 42, 287-297.

van Olphen, H. (1966): Maya Blue: a clay-organic pigment? Science, 154, 3749.

Veblen, D.R. \& Buseck, P.R. (1979): Chain-width order and disorder in biopyriboles. Am. Mineral., 64, 687-700.

Welch, M.D., Rocha, J., Klinowski, J. (1992): Characterization of polysomatism in biopyriboles: double-/triple-chain lamellar intergrowths. Phys. Chem. Miner., 18, 460-468.

Zoltai, T., (1981): Amphibole Asbestos Mineralogy. in "Amphiboles and other Hydrous Pyriboles - Mineralogy", D.R. Veblen, ed. Rev. Mineral., 9A, Mineralogical Society of America, Chantilly, VA, 249-278.

Received 26 October 2010

Modified version received 18 March 2011

Accepted 18 March 2011 